\title{
EKONOMISASI PEKARANGAN UMAT HINDU BERLANDASKAN TRI HITA KARANA
}

\section{ECONOMICATION OF HINDU'S LANDSCAPE ON TRI HITA KARANA PERSPECTIVE}

\author{
Ni Nyoman Satya Widari ${ }^{*}$, Ni Putu Ari Aryawati ${ }^{1}$ \\ ${ }^{1}$ Institut Agama Hindu Negeri Gde Pudja Mataram, Mataram, Indonesia \\ *Email Penulis korespondensi: satyawidari21@gmail.com
}

\begin{abstract}
ABSTRAK
Penelitian ini bertujuan untuk mengetahui persepsi Umat Hindu di Kota Mataram tentang pemanfaatan pekarangan, bentuk pemanfaatan pekarangan dan implikasi pemanfaatan pekarangan berlandaskan ajaran Tri Hita Karana. Penelitian ini menggunakan pendekatan kualitatif deskriptif dengan melakukan observasi langsung dan wawancara mendalam pada sepuluh orang responden serta studi dokumen. Deskripsi/gambaran tentang apa yang terjadi dan berusaha mendapatkan fakta yang terkait dengan pemanfaatan pekarangan oleh Umat Hindu di Kota Mataram Nusa Tenggara Barat. Hasil penelitian menyatakan bahwa persepsi Umat Hindu di Kota Mataram tentang pemanfaatan pekarangan berlandaskan Tri Hita Karana adalah mewujudkan keseimbangan yang berarti terwujudnya keharmonisan hidup terutama antara manusia dengan lingkungannya yang dalam Panca Yadnya berarti Bhuta Yadnya yaitu yang ditujukan kepada para Bhuta Kala yaitu unsur-unsur alam. Bentuk pemanfaaatan pekarangan Umat Hindu mengikuti pola pertanaman yang disebut Caraka dengan penempatan tanaman pada pekarangan disesuaikan dengan fungsinya pada setiap keluarga yaitu sebagai penyedia pangan, pelengkap upacara tradisional, bahan obat-obatan dan sebagai pemenuhan keindahan. Implikasi pemanfaatan pekarangan secara optimal oleh Umat Hindu berarti pula turut menjalankan prinsip palemahan yakni menjalin hubungan yang harmonis dengan alam sekaligus mengurangi ketergantungan akan bahan-bahan keperluan sehari-hari yang dibeli maupun didatangkan dari luar Kota Mataram.
\end{abstract}

Kata Kunci: Lingkungan, Harmonisasi, Caraka, Yadnya

\begin{abstract}
This study aims to determine the perception of Hindus community in Mataram about the use of the yard, the form of the use of the yard and the implications of the use of the yard based on Tri Hita Karana philosophy. This study uses a descriptive qualitative approach by conducting direct observations, indepth interviews and document studies. Description tell what happened and trying to get facts related to the use of yards by Hindus in Mataram City, West Nusa Tenggara. The results of this study stated that the perception of Hindus in the city of Mataram about the use of the landscape based on Tri Hita Karana is to create a balance which means the realization of harmony in life, especially between humans and their environment, which in Panca Yadnya means Bhuta Yadnya, which is addressed to the Bhuta Kala, namely the elements of nature. The form of utilization of the yard Hindus follow a cropping pattern called Caraka with the placement of plants in the yard according to their function in each family, namely as a provider of food, complementary to traditional ceremonies, medicinal ingredients and as a fulfillment of beauty. The implication of optimal use of the yard by Hindus also means participating in the palemahan principle, namely establishing a harmonious relationship with nature while reducing dependence on materials for daily needs that are purchased or imported from outside the city of Mataram.
\end{abstract}

Keywords: Environment, Harmonization, Caraka, Yadnya 


\section{PENDAHULUAN}

Pekarangan adalah sebidang tanah di sekitar rumah yang dibatasi pagar dan ada juga yang tidak dipagari. Pekarangan dimanfaatkan dengan ditanami beranekaragam jenis tanaman seperti tanaman yang berumur panjang, berumur pendek, menjalar, memanjat, semak, pohon rendah dan tinggi serta terdapat ternak. Pemanfaatan pekarangan oleh Umat Hindu yang mendesain sebuah taman atau lanskap untuk pekarangannya diupayakan sesuai dengan unsur Satyam (kebenaran), Siwam (kebersihan, kesucian, kemuliaan), Sundaram (keindahan, kecantikan, keharmonisan) yang menjiwai konsep Tri Hita Karana dan Tri Mandala (Suryada dan Bagus, 2012).

Tri Hita Karana adalah tiga sebab yang memberikan kebahagiaan, yaitu hubungan manusia dengan Tuhan, hubungan manusia dengan sesama dan hubungan manusia dengan lingkungannya. Konsep Tri Mandala (tiga areal) juga dipakai dalam konsep yang berkaitan dengan pengelolaan pekarangan ini, yaitu Utama Mandala adalah Parhyangan atau tempat suci atau pemerajan atau sanggah, Madya Mandala adalah pekarangan rumah yang meliputi bangunan tempat tinggal, dapur, kamar mandi, kerumpu atau jineng dan "teba" atau tegalan, sedangkan Nista Mandalaadalah pekarangan luar rumah atau jaba atau pekarangan sebelum memasuki pekarangan rumah (Dalem, 2015).

Berbicara mengenai pemanfaatan pekarangan dalam hal ini sasaran utamanya adalah perkotaan, karena dari hasil observasi masyarakat kota masih mempunyai lahan di sekitar rumah (pekarangan) yang bila dimanfaatkan dengan baik dapat memenuhi kebutuhan sehari-harinya seperti sayuran, buah-buahan, dan bumbu masak. Dengan demikian penelitian ini difokuskan pada daerah Kota Mataram yaitu Kecamatan Cakranegara. Kegiatan pemanfaatan pekarangan sudah sejak lama dilaksanakan, bukan saja sebagai penyedia bahan makanan yang beraneka ragam akan tetapi juga dapat berfungsi sebagai tambahan penghasilan keluarga/tabungan keluarga. Semua pekarangan belum dimanfaatkan secara baik. Banyak Lahan pekarangan hanya ditanami dengan beberapa komoditi saja, sedangkan ternak dan ikan belum dipelihara, padahal potensinya cukup tinggi. Selain itu, masyarakat belum dapat merancang pola tanam pekarangan dengan baik sehingga sering mengalami kekurangan bahan makanan seperti sayuran, buah-buahan dan umbi-umbian akibatnya menu keluarga kurang bervariasi, cenderung tidak seimbang dan hanya memenuhi sumber karbohidrat saja.

Berbicara mengenai pemanfaatan pekarangan dalam hal ini sasaran utamanya adalah perkotaan, karena dari hasil observasi masyarakat kota masih mempunyai lahan di sekitar rumah (pekarangan) yang bila dimanfaatkan dengan baik dapat memenuhi kebutuhan sehari-harinya seperti sayuran, buah-buahan, dan bumbu masak. Dengan demikian penelitian ini difokuskan pada daerah Kota Mataram yaitu Kecamatan Cakranegara. Pengelolaan lahan pekarangan selain dilatarbelakangi terus menurunnya lahan pertanian seiring pertambahan jumlah penduduk, juga potensi lahan pekarangan yang belum terkelola dengan optimal di seluruh Kota Mataram. Selain itu, sarana pengelolaan yang cukup tersedia, menjadikan alasan utama pemanfaatan lahan pekarangan.

Struktur tanaman di pekarangan dipengaruhi oleh faktor sosial budayaStruktur perkarangan setiap tahunnya sama, meskipun ada perbedaan-perbedaan menurut musim. Stratum terbawah (dibawah satu mater) didominasi oleh tanaman pangan yang mengandung zat perekat, sayur-sayuran dan rempah-rempah, umpamanya talas, lombok, terong dan lengkuas. Stratum berikutnya (antara satu dan dua meter) juga didominasi 
oleh tanaman dengan zat perekat lainnya, umpanya ganyong (canna edulis), Xanthosoma, singkong dan gembili (dioscorea esculenta). Tanaman yang biasanya banyak terdapat diperkarangan adalah singkong dan gayong. kedua jenis tanaman ini berkardar kalori tinggi, dan sangat penting sebagai pengganti beras. Stratum kedua (dua sampai lima meter) didominasi oleh pisang, pepaya dan pohon buah-buahan lainnya umpamanya nangka, mangga, jambu, rambutan, dan tanaman lainnya seprti . Stratum tertnggi, yaitu diatas 10 meter, didominasi oleh pohon-pohon kelapa dan pohon lainnya.

Konsepsi perwujudan perumahan Umat Hindu dengan pengelolaan pekarangannya merupakan perwujudan landasan dan tata ruang, tata letak dan tata bangunan yang dapat dibagi dalam : 1) Keseimbangan Alam: Wujud perumahan umat Hindu menunjukkan bentuk keseimbangan antara alam Dewa, alam manusia dan alam Bhuta (lingkungan) yang diwujudkan dalam satu perumahan terdapat tempat pemujaan, tempat tinggal dan pekarangan yang dikenal dengan istilah Tri Hita Karana, 2) Rwa Bhineda, Hulu Teben, Purusa Pradhana. Rwa Bhineda diwujudkan dalam bentuk hulu teben (hilir). Yang dimaksud dengan hulu adalah arah/ terbit matahari, arah gunung dan arah jalan raya (margi agung) atau kombinasi dari padanya. Perwujudan purusa pradana adalah dalam bentuk penyediaan natar. sebagai ruang yang merupakan pertemuan antara Akasa dan Pertiwi, 3) Tri Angga dan Tri Mandala. Pekarangan Rumah Umat Hindu secara garis besar dibagi menjadi 3 bagian (Tri Mandala) yaitu Utama Mandala untuk penempatan bangunan yang bernilai utama (seperti tempat pemujaan). Madhyama Mandala untuk penempatan bangunan yang bernilai madya (tempat tinggal penghuni) dan Kanista Mandala untuk penempatan bangunan yang bernilai kanista (misalnya: kandang). Konsep Tri Angga berupa kepala (sky-light, atap) - badan (dinding terbuka) kaki (lantai tinggi). Esensinya: Bentuk ruang 'sepasang setengah lingkaran' sebagai penyatuan perbedaan (Rwa Binedha); Tempat diskusi sekaligus olah jiwa adalah adaptasi arsitektural masa kini (Desa Kala Patra). Bukaan ke samping - ke atas sebagai relasi harmonis manusia - alam - Tuhan (Sombu, et al., 2019).

Perkembangan pola pikir manusia merupakan sebuah bentuk perkembangan yang mendasari terbentuknya suatu pemahaman yang merujuk pada terbentuknya sebuah makna. Apabila kita amati, kehidupan kita saat ini tidak pernah terlepas dari makna, persepsi, atau pemahaman terhadap apapun yang kita lihat. Semiotik bertujuan untuk mengetahui makna-makna yang terkandung dalam sebuah tanda atau menafsirkan makna tersebut sehingga diketahui bagaimana komunikator mengkonstruksi pesan. Konsep pemaknaan ini tidak terlepas dari perspektif atau nilai-nilai ideologis tertentu serta konsep kultural yang menjadi ranah pemikiran masyarakat di mana simbol tersebut diciptakan. Kode kultural yang menjadi salah satu faktor konstruksi makna dalam sebuah simbol menjadi aspek yang penting untuk mengetahui konstruksi pesan dalam tanda tersebut. Konstruksi makna yang terbentuk inilah yang kemudian menjadi dasar terbentuknya ideologi dalam sebuah tanda.

Dengan demikian, berdasarkan pemaparan di atas maka perlu kiranya dilakukan kajian tentang pemanfaatan (pengelolaan) pekarangan oleh Umat Hindu di Kota Mataram khususnya Kecamatan Cakranegara, sehingga lahan pekarangan dapat dikelola secara optimal baik sebagai penunjang pemenuhan kebutuhan keluarga sehari-hari maupun untuk penyediaan bahan-bahan untuk kegiatan ritual keagamaan. 


\section{METODE PENELITIAN}

Penelitian ini menggunakan metode kualitatif dengan melakukan pengamatan secara langsung dengan masyarakat serta informan-informan lainnya yang berkompeten di bidangnya. Penelitian ini dilakukan bulan Juni-September 2019 dengan pemilihan sampel purposive sampling. Wawancara dilakukan dengan cara struktur menggunakan pedoman wawancara kepada masyarakat dan dilengkapi oleh dokumen-dokumen lainnya. Penyajian hasil penelitian dilakukan secara sistematis, faktual dan akurat tentang pemanfaatan pekarangan oleh Umat Hindu di Kota Mataram.

\section{HASIL DAN PEMBAHASAN}

Konsep Agama Hindu adalah mewujudkan keseimbangan. Dengan terwujudnya keseimbangan, berarti terwujud pula keharmonisan hidup yang didambakan oleh setiap orang di dunia. Untuk Umat Hindu yang diidam-idamkan adalah terwujudnya keseimbangan antar manusia dengan Tuhannya, antara manusia dengan manusia dan manusia dengan lingkungannya. Maka dari itu, Yadnya mutlak diperlukan. Ada dua macam Panca Yadnya, yaitu: 1. Panca Yadnya berdasarkan sarana dan bentuk pelaksanaannya, 2. Panca Yadnya berdasarkan tujuan dan objek yang dituju, Yadnya ini disebut Panca Maha Yadnya. Dalam kitab Manawa Dharmasastra III. 70 tersurat:

"Adhyapanam brahma Yajnah,

pitryapastu tarpanam,

homo daiwo balikbaurto,

nryajna 'tihti pujanam."

Artinya :

Mengajar dan belajar adalah Yadnya bagi Brahmana, menghaturkan minyak, susu adalah Yadnya untuk para Dewa, menghaturkan bali adalah Yadnya untuk para bhuta, dan penerimaan tamu dengan ramah tamah adalah Yadnya bagi manusia.

Tanaman yang sering digunakan oleh umat Hindu dalam pelaksanaan upacara adalah sebagai berikut :

Kelapa (Cocos nucifera) adalah anggota tunggal dalam marga Cocos dari suku aren-arenan atau Arecaceae. Tumbuhan ini dimanfaatkan hampir semua bagiannya oleh manusia sehingga dianggap sebagai tumbuhan serbaguna, terutama bagi masyarakat pesisir dan masyrakat Hindu. Bagi masyrakat Hindu, pohon kelapa tidak dapat dipisahkan dari kegiatan keagamaan. Masyarakat Hindu - Bali menggunakan hampir semua bagian dari pohon kelapa antara lain seperti: 1. Busung (Janur) biasanya dipergunakan untuk membuat peralatan upakara yang sering disebut banten. 2. Slepan (daun kelapa warna biru) mempunya fungsi yang sama dengan janur yaitu dipergunakan untuk sarana upakara. 3. Danyuh (daun kelapa tua) biasanya dipergunakan untuk kayu bakar dan sapu lidi. 4. Klungah (buah kelapa muda yang hanya berisi air) biasanya dipergunakan sebagai sarana untuk penyucian diri dan juga merupakan sarana untuk upacara keagamaan dan adat untuk umat Hindu etnis Bali. 5. Buah kelapa yang sudah tua biasanya dipergunakan untuk sarana upacara berupa pejati dan daksina sebagai dasar dari kegiatan keagamaan. 6. Pohon kelapa sudah dari dahulu sebagai bahan bangunan, kukul (kentungan), bedug (kendang), tangkai cangkul dan yang lainnya. 
Kelapa yang merupakan unsur terpenting dari berbagai jenis kelengkapan upakara seperti dalam padudusan, pecaruan Rsi Gana, labuh gentuh dan pecaruan besar lainnya. Kelapa gading (kuning) di barat untuk Dewa Mahadewa, kelapa bulan (putih) di timur untuk Dewa Iswara, kelapa hijau di utara untuk Dewa Wisnu, kelapa udang (merah) di selatan untuk Dewa Brahma, dan kelapa sudamala (campuran keempat warna) di tengah untuk Dewa Siwa. Jenis kelapa yang lain dan juga digunakan dalam kelengkapan upakara adalah kelapa bojog, rangda, mulung, dan julit. Penanamannya di luar natah, di sekitar dapur, areal pekarangan, dan tegalan.

Tanaman jambe atau pinang terdiri dari beberapa jenis, seperti buah pinang sari, buah gangga, dan jenis buah pinang lainnya akan lebih baik ditanam di bagian selatan atau daksina karena sebagai perlambang dari Sang Hyang Brahma. Tanaman siulan sebaiknya ditanam di bagian barat atau pascima, banyak dipakai dalam sarana upacara kwangen dan sesajen lainnya. Tanaman teleng biru akan lebih baik kalau ditanam di bagian utara atau uttara, digunakan dalam setiap sesaji. Tanaman tunjung atau teratai yang terdiri dari berbagai macam warna, yang dipakai di berbagai keperluan upakara dewa-dewi, penempatannya di pekarangan mengikuti warnanya yaitu biru di utara, putih di timur, merah di selatan dan kuning di barat.

Pisang merupakan salah satu tanaman yang umat Hindu manfaatkan sebagai bentuk persembahan baik itu dari buah, daun hingga batang. Pisang (Musa paradisiaca L.) merupakan tumbuhan daerah tropis karena menyukai iklim panas dan memerlukan matahari penuh. Tanaman ini dapat tumbuh di tanah cukup air pada daerah dengan ketinggian sampai 2000 meter di atas permukaan laut.

Kayu Cendana (Santalum album L.). Kayu cendana juga sangat disakralkan oleh masyarakat Hindu Etnis Bali, dimana kayu cendana (Santalum album L.) ini digunakan dalam pembuatan pelinggih karena kayu ini menghasilkan aroma yang sangat wangi, sehinngga kayu ini bagus untuk digunakan di tempat-tempat suci. Selain digunakan dalam pembuatan pelinggih, kayu cendana ini juga dapat digunakan dalam pembuatan pratima, dimana kayu ini merupakan peragan dari bhatara Paramasiwa. Dalam klasifikasi kayu menurut orang Bali, kayu cendana ini termasuk golongan kayu prabu, artinya kayu ini biasanya digunakan untuk membuat langit-langit dalam suatu pelinggih.

Alang-alang (Imperata cylindrical L.). Filosofi alang-alang dalam ajaran Hindu banyak dikaitkan dengan pemuteran Mandara Giri, dimana Para Dewa dan Asura bekerja sama memutar Mandara Giri, Hyang Ananta Boga dan Hyang Besuki melilit Mandara Giri, dan sebagai penopangnya adalah Badawang Nala. Disimbolkan dalam wujud Padmasana. Setelah keluar Amerta-nya dilarikan oleh Daitya Kala Rau (Rawi), tapi ketahuan Dewi Ratih dipanahlah kepalanya dengan Senjata Cakra oleh Dewa Wisnu. Dari situ ada cerita bulan Kepangan (Bulan caplok kala rawu). Sebelum sempat diambil oleh Ida Hyang Wisnu, sempat menetes sedikit ke rumput alang-alang, terus dijilati oleh para naga/ular sehingga ular bisa berumur panjang dan lidahnya tersayat (terbelah) oleh alang-alang. Maka dari itu alang-alang juga disebut tanaman panjang umur atau tanaman suci yang merupakan menjadi bahan penting dalam beberapa upacara keagamaan Hindu.

Bambu merupakan tanaman yang paling sering digunakan dalam upacara keagamaan Hindu Etnis Bali. Pada bangunan, kerangka atapnya menggunakan kayu dan bambu khususnya untuk iga-iga-nya. Bambu bila telah dianyam juga sering digunakan untuk dinding-dinding bangunan dan pagar pembatas rumah. 
Pemanfaatan pekarangan oleh Umat Hindu di Kota Mataram dipersepsikan sebagai upaya mewujudkan keseimbangan yang berarti pula terwujudnya keharmonisan hidup terutama antara manusia dengan lingkungannya yaitu unsur-unsur alam. Pengetahuan tumbuhan sebagai simbol penyusun tubuh merupakan salah satu persepsi masyarakat Hindu etnis Bali terhadap eksistensi dirinya yang dilambangkan dengan berbagai jenis tumbuhan. Secara prinsip Umat Hindu di Kota Mataram dengan pengelolaan pekarangan merupakan satu bentuk mencari keharmonisan dengan alam.

Implikasi pemanfaatan pekarangan yang berlandaskan Tri Hita Karana terhadap Umat Hindu di Kota Mataram bahwa dengan memanfaatkan pekarangan secara optimal berarti turut menjalankan prinsip palemahan yakni menjalin hubungan yang harmonis dengan alam sekaligus mengurangi ketergantungan akan bahan-bahan keperluan seharihari yang dibeli maupun didatangkan dari luar Kota Mataram. Optimalisasi lahan pekarangan (pengelolaan yang baik) dapat berkontribusi dalam mempermudah mendapatkan keperluan sehari-hari (sumber pangan), obat-obatan (herbal) dan meringankan saat upacara (pembuatan upakara).

\section{KESIMPULAN DAN SARAN}

Pemanfaatan pekarangan oleh Umat Hindu di Kota Mataram dipersepsikan sebagai upaya mewujudkan keseimbangan yang berarti pula terwujudnya keharmonisan hidup terutama antara manusia dengan lingkungannya yaitu unsur-unsur alam. Penempatan tanaman pada pekarangan disesuaikan dengan fungsinya pada setiap keluarga yaitu sebagai penyedia pangan, pelengkap upacara (tradisional) dan kegiatan sosial, untuk bahan obat-obatan dan rempah serta sebagai pemenuhan keindahan dan seni. Implikasi pemanfaatan pekarangan yang berlandaskan Tri Hita Karana terhadap Umat Hindu di Kota Mataram bahwa dengan memanfaatkan pekarangan secara optimal berarti turut menjalankan prinsip palemahan yakni menjalin hubungan yang harmonis dengan alam sekaligus mengurangi ketergantungan akan bahan-bahan keperluan seharihari yang dibeli maupun didatangkan dari luar Kota Mataram.

\section{DAFTAR PUSTAKA}

Adriani A. (2008) Jenis,Status dan Pemanfaatan Tumbuhan Jenis Pohon di Desa Adat Baturning Kecamatan Abiansemal, Kabupaten Badung Bali.

Neolaka, A. (2008). Kesadaran Lingkungan. PT. Rineka Cipta: Jakarta.

Bahrudin, S. (2009). Berbakti Untuk Bumi, Bandung: Rosdakarya.

Dalem, A. A. G. R. (2015). Pengelolaan Lingkungan Berbasis Kearifan Lokal: Studi Kasus Di Bali. Universitas Udayana Bali.

Dibyasuharda.(1990). Dimensi Metafisik Dalam Simbol ; Ontologi Mengenai Akar Simbol. Universitas Gadjah Mada Press: Yogyakarta.

Dwiana, F. A., Yarmalinda, D., Rahayu, D., Devi A., Yuliani, W., Amelia, R.,\& Halimah, N. (2013). Ekosistem Pekarangan Desa dan Talun. Universitas Islam Riau.

Huasein, H.M. (1993). Lingkungan Hidup: Masalah Pengelolaan dan Penegakan Hukumnya. PT. Bumi Aksara: Jakarta.

Suprayogo, I.,\& Tobroni. (2001). Metodelogi Penelitian Sosial Agama. PT Remaja Rosdakarya: Bandung 
Otto Soemarwono, (1994. Ekologi Lingkungan Hidup dan Pembangunan. Djambatan: Bandung.

Prapanca. (2005). Bertanam Sayuran Organik di Kebun, Pot dan Polibag. Penebar Swadaya: Jakarta.

Redaksi Trubus. (2009). Bertanam Sayuran di Lahan Sempit. Edisi revisi. Penebar Swadaya: Jakarta.

Sardiana. (2010). Studi Pemanfaatan Tanaman Pada Kegiatan Ritual (Upakara) oleh Umat Hindu di Bali.

Sombu, A. S., Herwindo, R. P., Arif, K. A., \& Kharismanto, A. R. (2019). Pelestarian tradisi budaya Bali dalam arsitektur bangunan publik masa kini: pada bangunan Mandala Agung Puri Ahimsa di Desa Mambal-Bali.

Sugiyono. (2010). Metode Penelitian Kuantitatif, Kualitatif dan R\&D. CV. Alfabeta: Bandung.

Suprayogo, I \& Tabroni. (2001). Metodologi Penelitian Sosial-Agama. PT. Remaja Rosdakarya: Bandung.

Suryada, I. G. A. B., \& Bagus, G. A. (2012). Konsepsi Tri Mandala dan Sangamandala dalam Tatanan Arsitektur Tradisional Bali. Sulapa, 4(1), 23-32.

Titib, I. M. (2001). Teologi \& Simbol-Simbol Praktis Kehidupan. Paramita: Surabaya. Triguna, I.B.Y. (2000). Teori Tentang Simbol. Widya Dharma: Denpasar. 